DOI Number: 10.30520/tjsosci.509891

\title{
NEW APPROACHES OF EMOTIONAL LABOR PROCESSES IN THE MODERN ORGANIZATIONS
}

MODERN ORGANIZASYONLARDA DUYGUSAL EMEK

BOYUTLARI

Hale Nur GÜLER ${ }^{1}$

Akın MARŞAP ${ }^{2}$

\begin{abstract}
Emotional labor, known as managed emotions, is exhibited in the face of communication with the service areas in order to adapt to the rules that the organizations have stated. The aim of emotional labor in this study is that organizations can be understood better in terms of employees. The literature survey for this purpose has provided emotional labor approaches, emotional labor dimensions, and the results of emotional labor. In the light of the obtained information; "Concept and concept of emotional labor" was interpreted in order to extract, evaluate, develop and correctly apply the first output in terms of a certain limited view in 1981, in a broader angle of $360^{\circ}$ in modern business life. Thus, contemporary business organizations are expected to provide more humanitarian work conditions, realistic business relationships and a satisfying work environment, as well as increased productivity, quality, creativity and innovation.
\end{abstract}

Keywords: Emotional Labor, Rules of Emotional Labor, Emotional Labor Approaches, Emotional Labor Process, Modern Organizations, Results of Emotional Labor

\section{ÖZET}

Yönetilen duygular olarak bilinen duygusal emek, kurumların belirtmiş oldukları kurallara uyum sağlamak amaciyla sergilenmekte ve özellikle hizmet sektöründe önemini sürdürmektedir. $\mathrm{Bu}$ çalışmanın amacı duygusal emeğin hem kurumlar hem de çalışanlar tarafından daha anlaşılır hale getirmektir. Bu amaçla literatür taraması yapılarak duygusal emek yaklaşımları, duygusal emek boyutları ve duygusal emeğin yol açtığı sonuçlar incelenmiştir. Elde edilen bilgiler ışığında duygusal emeğin ilk ortaya çıkartıldığı 1981 yılındaki sınırlı bakış açısının dışına taşıyarak modern iş yaşamında 360 derecelik daha geniş bakış açısıyla değerlendirmek, geliştirmek ve daha etkin şekilde uygulanabilmesi için duygusal emek kavramı yorumlanmıştır. Çalışmada elde edilen bilgilerin çağdaş organizasyonlarda daha fazla insani çalışma koşulları, gerçekçi iş ilişkileri ve tatmin edici çalışma ortamı yaratması, diğer yandan yöneticiler ve çalışanlar için verimlilik, kalite ve yaratıcılık sunması beklenmektedir.

Anahtar Kelimeler: Duygusal Emek, Duygusal Emek Kuralları, Duygusal Emek Yaklaşımları, Duygusal Emek Süreçleri, Modern Organizasyonlar, Duygusal Emek Sonuçları

\footnotetext{
${ }^{1}$ Dr. İstanbul Aydın Üniversitesi, Sosyal Bilimler Enstitüsü, İşletme Bölümü. halgu76@gmail.com

${ }^{2}$ Prof. Dr., İstanbul Aydın Üniversitesi, İktisadi ve İdari Bilimler Fakültesi, Uluslararası Ticaret Bölümü. akinmarsap@aydin.edu.tr
} 


\section{Introduction}

The sensetive changing and strengthening of competition conditions is also important in the service sector. Employees are very important success criteria in the stages of change and development of organizations. It is also necessary that the behavior of the employees should be shaped and managed while expecting that their contribution will be positive. For this reason, employee behaviors have become important in terms of organizations in recent years. The outcomes of employee behavior also affect customers and employees.

Emotions are generally influenced by both individual and organizational factors and transform into behavior. The more effective the emotional labor demonstration, the more positive the results created for customers and organizations become. Emotional labor demonstrations increase the profitability and brand value of organizations. Employees have become obliged to manage their emotions and to ensure that service areas are well separated. Emotional labor, which is called emotional effort exhibition by shaping emotions in the frame of rules that organizations put into it, is a significant success factor. There are several factors that affect emotional labor.

Differences shape your emotional labor-sense. Deep understanding of emotional labor will make it easier to manage and exhibit by raising awareness of its implementation, supervision and understanding of its positive and negative consequences, while being important to managers, employees, customers and even organizations. In this article, the stages of emotional labor, including the 1980s, where the first definitions were made during the historical process that began in the 1960s, when the first reflections of the emotional labor were revealed, are studied as a day museum in a literary work. This work presents a new perspective on the processes of daily emotional labor application from the past to today.

In this study, the emotional labor process tried to enrich by bringing a new perspective. The processes of emotional labor demonstration are discussed in five stages, in addition to the basic pamphlets that guide emotional labor. Thus, emotional labor is taken from a wider perspective by subtracting the start-up from the narrow side, and by increasing its functionality, the relationship between the premises and the ends is tried to be established within a certain flow and logic.

It is stated that emotional labor is required to be understood and applied in a deep way by all shareholders in an organization that has only one theory and no more conformity. Thus, in addition to providing good communication and interaction in the organization, productivity performance and quality of the organization are foreseen. Increasing the trust and trust of employees at all levels is expected to contribute to a higher level of harmony and cooperation among employees.

\section{Different Definings of the Emotional Labor}

Service areas in the changing and evolving service sector are increasingly anticipated from the firms. One of the critical and most important resources that need to be managed in order for firms to be successful in the industry is human resources. For this reason, the attitudes of the personnel within the company are important and subject to many researches. Personnel contributes to the success of the companies with the behavior they show towards the internal customer, and also the external customer. 
Hoschild defined emotional labor as a form of facial and physical representation arranged in such a way that the emotional labor, the emotional labor, and the emotions required by the work are observed by others (Diefendorff et al., 2005: 339). According to Hoschild, emotional labor refers to the emotions of service workers, their emotions, their regulation, and their commercial emotions. It can also be expressed as a sense of facial and physical image creation that can be observed publicly (Hoschild, 2003: 7).

Emotional labor, sociology, psychology and behavioral sciences have been the subjects of many studies. Emotional labor, which is known as the management of emotions, takes place especially in the service sector. Because, in the service sector, emotional labor is needed besides mental and organizational activities (Beginirbaş and Yalçın, 2012: 28). (Grandey, Diefendorff and Rupp, 2013: 9), who are involved in the service sector, are teachers, health workers, call center workers, law workers, bank employees, guides from tourism sector employees and receptionists.

Emotional labor is also defined as the emotional regulation that has been introduced to cope with the emotions of others (James, 1989: 15). Emotional labor is the effort given to the organization of emotional images so that employees can fulfill organizationalbased expectations (Brotheridge and Lee, 2003: 365). In general, emotional labor is the management of emotions for organizations and jobs in order to comply with the rules of emotional behavior. Emotional labor is not easy to show. It is quite troublesome for a worker to try to be happy and helpful while he is not on a good day. This situation, which is caused by the duty to be performed, can also cause emotional incompatibility (Grandey, 2000: 95-110).

Since Tasks and Huang, 2002: 1001-1008), organizations are constantly striving to increase the quality of service, and customers are constantly raising expectations and stimulating this situation in order to meet the needs, the organizations follow the technology in the best way while paying attention to the training and motivation of the personnel.

While customers evaluate the organization, they take into account how the staff responds to the problems that arise from measuring the quality of knitwear while assessing how they behave towards them, the precautions taken and the opportunities offered. In the developing and changing world, for example, quality in the health sector is criticized by parents and patients very much (Gray, 2012: 3).

Emotional labor is therefore important for all these reasons. Managing emotions ensures that organizations work without problems (Saks, 1990: 111). Human resources are the most important values of the companies. Emotional labor practices of employees are important in achieving organizations' goals and job satisfaction. In summary, emotional labor is the interaction with the customers when the service is being done and the emotions desired by the organization are exhibited. The following are definitions of emotional labor that are frequently found in the literature (Hsieh, 2009: 11).

- Hoschild (1983) is the management of emotions in order to create observable facial expressions and physical representations.

- Ashforth and Humphrey (1993) is the display of emotions appropriate to the rules of emotional behavior.

- Morris and Feldman (1996) Effort, planning and control are needed to express the emotions desired by organizations in communication between individuals. 
- Kruml and Geddes (2000) are behavior patterns in which employees feel certain emotions to guarantee and standardize the service quality offered to customers, or when it is necessary to plan certain feelings at least.

- Grandey (2000) The pattern of emotional behaviors that the group expects involves involvement, empowerment, or suppression to change emotional expressions.

- Chu (2002) is the degree to which a person's behavior or intrinsic feelings are relayed in order to exhibit appropriate emotions in response to emotional codes of conduct and professional norms.

- Brotheridge and Lee (2003) describe behavioral responses to changes in intensity, duration, and frequency of service interactions.

- Diefendorff and Gosserand (2003) are the process of controlling and reducing the variability of emotional expressions and the constant comparisons of the perception of emotional conduct rules.

- Glomb and Tews (2004) focus primarily on expressing feelings that are felt or not in harmony with behavioral expressions and emotional behavioral rules.

- Johanson (2007) is the expression of emotions that service organizations offer when they are served.

- Guy et al. (2008) Employees use their emotions, suppression, or their emotions by putting their emotions into the business process while performing their duties.

As a result, emotional labor is to carry out the successful transfer of information obtained in holistic life processes in a highly harmonized team work by continuing the sharing of effective transfer at cognitive and emotional level in the modern organizations.

\section{3-Emotional Articulation Rules}

The place of emotions in business life is great. Particularly in the service sector, employees offer their service feelings. At this stage, certain rules may be required for how emotions can be displayed. Because the service to be offered to the customers must be given in accordance with the standards determined by the company. Because of this, most of the organizations express the emotions and emotions that their employees should show to the customers (Diedendorff and Gosserand, 2003: 950).

The display rules are defined by the psychologist Paul Ekman as norms of emotional expressions displayed during service presentation. Accordingly, behavior standards set forth display rules for how well these feelings are appropriate, as well as how these feelings should be exhibited and how they can be communicated. In general, every organization has rules on how to treat customers (Duran and Gümüş, 2013: 237):

Community rules define how a good service should be presented. According to professional groups, the rules are different. Once the structure of the society and the rules related to the profession are known, the employees can be supervised by the managers and try to catch certain standards. Various sanctions can be made if there are differences in compliance with the rules of emotion indicated by the companies. Emotional behavior rules differ from the service offered and the firm to the firm. 
The emotional labor laws that organizations put forward affect emotional labor demonstrations. These rules must be executed correctly and effectively. It depends on the construction of each parameter that makes up the specified rules with the most accurate and most humanistic approach, taking care of the whole with sensitivity. In addition to emotional labor laws, there are also different parameters affecting emotional labor performances. The basic parameters that guide the emotional labor during emotional labor demonstrations are ten great parts:

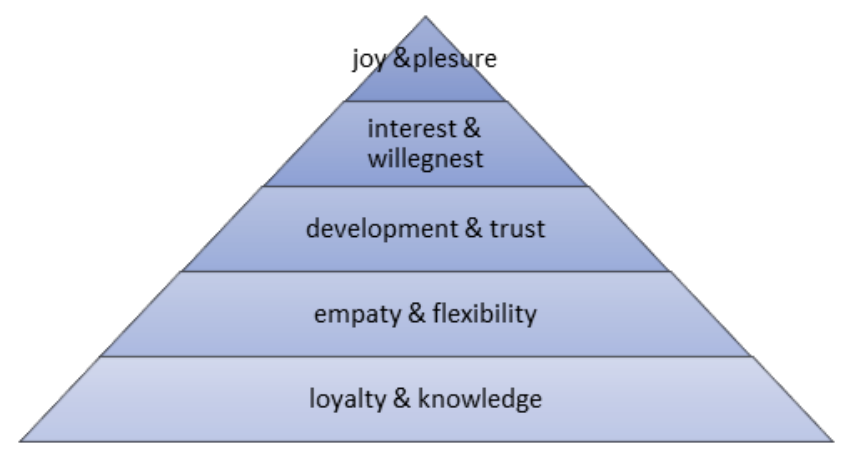

Figure.1. Ten Great Elements In The Emotional Labor Process

\section{Emotional Labor Approaches in the Modern Organizations}

Hoschild's emotional work began in 1960, inspired by Goffman, known as an observer genius. Hoschild's concern with how his feelings are managed by his own expressions is due to his parents witnessing the interpretation of their guests' gestures and mimics when they entered the US Department of State service (Hall, 2015: 22). Hoschild describes the audience as the audience, the employees, the actor, the workplace as the stage while communicating with the customers, and this living process is considered as the play put on the stage. According to Hoschild, there are general anticipations about providing appropriate emotional responses to staff when providing services. These anticipations are caused by the norms that determine the intensity and diversity of the purpose of the feelings that must be felt.

Therefore, there are some forms of emotional labor display required by some professional groups. For example, call center employees are expected to smile, be serious about cops, be helpful and helpful from doctors, and not overreact to a wound they see from emergency medical intervention specialists (Mastracci, Guy and Newman, 2014: 42; Fineman, 2003: 40). It can be said that different emotions should be displayed for each profession group.

Hoschild divided occupational groups into two groups: emotional laborers and nonemotional laborers. In this context, there are three characteristics to the need for emotional labor in a profession. First, employees must interact with customers centrally or by phone. Secondly, employees should keep the customers' feelings in the foreground. Third, the interactions of customers and employees must be under the control of organizational managers. Where these three components are, there may be emotional labor (Hochschild, 1979: 551; Smith 1992: 7). Emotional labor is often an undetectable face, being an inseparable part of the speed-text, being portrayed as shadow labor (James, 1993: 95-96; Xiao-Yu et al., 2016: 1-26). 
The rules in which emotions, how, when, and what emotions are shown are determined in business life (Grandey et al., 2013: 25, Hoschild, 2003: 52, Theodosius, 2008: 225). As these rules require, Hoschild generally describes this situation with two different types of behavior. The first is surface-act, which is like a feeling of feeling that one does not really feel. Call center employees are examples of this. The second type of behavior from emotional labor displays is deep act. In-depth behavior is to really try to feel and feel the emotions that are meant to be seen (Approval, 2011: 587). Both in-depth and superficial behavior can be challenging (Debesay et al., 2014: 74). In-depth behavior is related to positive aspects of emotional labor such as job satisfaction, emotion enhancement, and customer satisfaction (Chou et al., 2012: 502, Golfenshtein and Drach-Zahavy, 2015: 112). Superficial behavior is related to emotional incompatibility, inconsistency between emotions (Cheng et al., 2013: 282 and Karimi et al., 2014: 176).

The second approach in this regard is Ashforth and Humphrey's approach. Unlike Hoschild, Ashforth and Humphrey describe emotional labor as a demonstration of appropriate emotional behavior. Because, according to Ashforth and Humphrey, what is important is not to focus on the underlying feelings of behavior, but to focus on observable behaviors. They argued that emotional labor creates a kind of impression. Creating an impression is the process of directing or changing someone's thoughts about himself or herself (Ashfort and Humphrey, 1993: 89). Creating impressions people are known to want others to think better about themselves and they show behaviors that can be considered appropriate by everyone.

Ashforth and Humphrey, in addition to the superficial and in-depth behavioral patterns of Hoschild's emotional labor, have also included sincere behavior. The behavior that should be shown in the sincere behavior put forward by Ash-forth and Humphrey is really felt and shown. According to Ashforth and Humphrey, the more the employee identifies himself with the rules of emotional behavior determined by the corporation, the more sincere he may be. Because in this case the staff will not act because of the rules that they adopt and will act sincerely. (Grandey, 2000: 5). Ashforth and Humphrey have made changes in the results of the emotional labor approach. The results of emotional labor are sometimes positive and sometimes negative, depending on the situation. Since emotional labor is the behavior that the organization wants to show, employees also develop their own behaviors and develop their ability to express themselves in order to do so.

On the other hand, if employees do not feel they should try to adapt themselves, it can cause discomfort in them. Emotional conflicts arise, they lose their respect and increase their desire to leave work (Savaş, 2009: 51). Ashford and Humphrey assert that when the profound and superficial behavior is observed, the employee must strive and focus, while in sincere behavior, it develops spontaneously (Pala and Sürgevil, 2016: 76).

It is a very tiring task to try to appease his nervousness by engaging with a nervous client by pretending to feel like he feels like he is not feeling in the service sector after all these ways, and even after effective communication and intentions are achieved, the staff continues to suffer from fatigue. In Morris and Feldman's approach, it is defined by researchers as "the level of effort, planning and control that an organization has spent in order to exhibit emotions that the organization expects of itself as long as the employee is related to other individuals" (Walk, 2011: 3828). 
According to the approach, the effort is being made to show the labor even if the employee has the same expectation as the employee expects. For example, if you are interested in approaching a patient who is waiting for compassion, though, you really need to be self-sacrificing, even if you really feel responsible and willing to help. Examples of behaviors exhibited by physicians and nurses working in emergency services in the face of events they experience are examples of this behavior. Morris and Feldman examine emotional labor as a dimension of emotional labor rather than derinse, superficial, and sincere behavior, including different interchanges. In this approach, emotional labor can vary according to circumstances. These dimensions are listed as follows (Morris and Feldman, 1996: 986-1010):

- Emotion display frequency

- Attention to given emotional behaviors

- Variety of emotions to reflect

- Emotional conflict

Frequency of showing emotions; how often the expected behaviors of the employees are expressed. The frequency of employees showing emotional behavior and the more important it is for the organization, the higher the prevalence of emotional codes of conduct (Young, 2013: 14). On the other hand, the frequency of feeling impressions varies according to professions. Attention to the indicated rules of emotional behavior; more psychological and physical effort is required. For this reason, more emotional labor is used in these qualitative works (Güngör, 2009: 172).

This process is examined in two categories. These are the periods of display of emotions and the intensity of emotions. The more intense the emotion is in this case and the longer it is done, the more attention will be paid to it. While there is little labor in a customer relationship in a short period of time, more labor is shown to keep the emotions alive as time elapses (Öz, 2007: 11-12). For example, nurses interact with their patients for a long time when the cashiers have a short-term relationship with their clients (Güngör, 2009: 172-173).

Employees who are forced to exhibit more than one emotion will have more planning and control their own behavior, which means more mental and physical effort (Güngör, 2009: 173). Emotional contradiction; there are emotional contradictions when the emotions of the employees do not overlap with the rules determined by the organizations. The victimization of the client receiving the faulty service may experience emotional conflict while trying to empathize to appease the customer (Morris and Feldman, 1996: 986-1010).

It is known that the cashiers are only satisfied with the customers' demers and smiles, while the nurses are more concerned with the emotional labor they need to show, in relation to the patient. The variety of emotions that need to be reflected; The difference in emotions that must be shown to the customers is related to the Show end. Wharten and Ericson are classified as complementary, differentiating and masking, while Morris and Feldman distinguish positive, negative and neutral by what needs to be reflected. Positive emotions are aimed at employees to think well, negative feelings to be angry and hostile, and neutral to be neutral (Savaş, 2012: 55).

It is defined as the effort spent in setting the emotions of grandey's emotional labor approach as follows (Değirmenci, 2010: 14). Grandey expressed emotional labor as a 
process of emotional adaptation by using the concept of "emotion regulation" as a process in psychology.

Emotion regulation is the emotion regulation that is based on the opinion of where and how one should express his / her emotions when he / she confronts any event. Employees control their emotions and respond appropriately to comply with the display rules required by their work (War, 2012: 57).

In Grandey's approach, three other approaches were combined and a new model was created. In this model, a focus on predestined emotion regulation and reaction focused emotion is included. Preconditioned emotion regulation consists of the following items (Grandey, 2000: 8):

- Selecting the environment

- Changing the environment

- Converting attention to a different direction

- Cognitive exchange

Selecting the environment; to approach the emotions that certain emotions will create or to escape from the environment. An example of a meeting with an angry customer is to give him a statement in order to avoid a centenary. Changing the environment; positive or negative emotions can create a difference on the environment. When turning attention away, the employee thinks or does things that make him feel good in the working life. The music can be played during the work or during the lunch break, for example, in the sports complex of the company. Cognitive change is the evaluation of the existing situation differently.

For example, a vehicle that sounds horn may be uncomfortable, but when it appears to be sick inside the vehicle, the emotions change and the begins to be evaluated differently (Özgen, 2010: 29). When there is a difference between the situation seen at the first stage and the situation understood later, feelings change. Cognitive change examples, self-talk, rethinking the situation as something more challenging than stressful (Totterdell and Holman, 2003: 55).

The active life cycle of emotional labor consists of successive steps. In this sense, the emotional labor process occurs during the activities of individuals and groups within the organization. The choice of which type of emotional labor to apply to the different situations that arise is done within the context of emotional state adaptation, both internal and external. After that, the emotional labor is displayed at different levels. Finally, after the screening, emotional labor is revealed for the employees, the organization, the customer and all the shareholders. These outputs can be clearly assessed by Emotional Labor Specialists (ELS) depending on their knowledge and experience. The active life cycle of emotional labor can be shown as follows. 


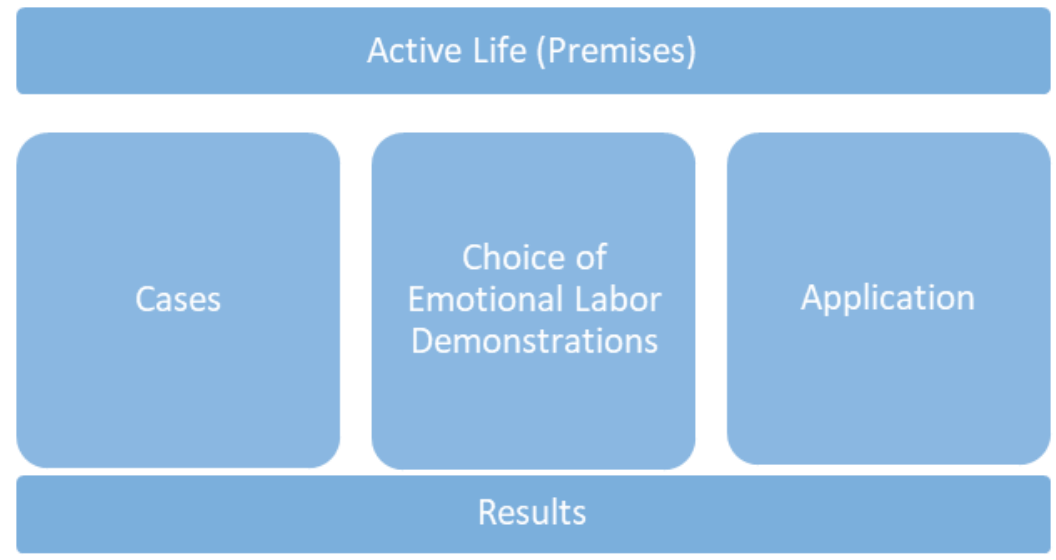

Figure.2. The Active Life Cycle Of Emotional Labor

\section{Transaction From Three Emotional Labor Process Toward Five Emotional Labor System}

Workers in superficial behavior act as if they are feeling, that is, they adjust only the reactions they give without internalizing the emotion. Employees are showing feelings and feelings. Superficial behavior is a form of behavior that aligns employees' feelings with their expected behavior without actually altering their feelings (Grandey, 2003: 86). Although they do not really feel, emotional behavior rules refer to a strategy for changing emotional indicators as required (Yin and Lee, 2012: 56; Zembylas, 2002: 187).

For behaviors desired to be exhibited by organizations, employees behave counterfeit when they do not add their own feelings (Cheung and Tang, 2009: 75-76). It has been seen that superficial behavior is expressed as a kind of pretending to act or acting. In superficial behavior, the presentation reaches the opposite side by acting with verbal and nonverbal cues such as face expression, gestures and tone of voice. Workers in superficial behavior act as if they are in a positive affirmation by suppressing the negative emotions they feel. Employees do not really feel the feelings they have to exhibit here. In the face of a customer insulting them, they act in the same courtesy without losing the positive expression, and they oversell as if nothing has happened with the customer (Mark, 2005: 304).

In an attempt to reconcile his feelings of self-anticipated behavior, he is in a process of changing his / her emotions with cognitive techniques (such as self-conviction) in order to exhibit emotional expressions that are required by the rules of emotional behavior (Grandey, 2003: 13). This behavior, which is different from superficial behavior, tries to harmonize not only its movements but also its feelings with its behavior. It does not try to harmonize its inner thoughts and emotions, working in the way it is described in emotional conduct codes (Chang, 2011: 22).

Trying to be adapted to emotions that actually feel emotions should be should be a cognitive change so that appropriate emotions can be felt (Zapf et al., 1999: 375, Gelderen, Konijin and Bakker, 2016: 852). In order to be effective when deeper behaviors are shown, it is necessary to change the inner feelings so that the necessary feelings can be felt (Zapf et al., 1999: 371). 
Sincere behavior is the type of behavior exhibited by employees in order to feel the emotions they have to express (Köksel 2009: 35). For example, treat a doctor's patient's life on the loss of his life. Morris and Feldman stated that even if the employee's real feelings and the expected emotions are the same, the work still has to make a certain effort. It is known that sincere behavior is the cause of the positive responses of service areas (Hennig-Thurau et al., 2006: 60).

Employee empathize with the client, try to understand the reasons that annoy him and turn him into a difficult customer, and behave in a more in-depth approach to positive emotions (Gülova and Palamutçuoğlu, 2013: 45). In general, it can be said that the most in-depth behavior is expected to be the type of emotional labor.

It is also important to what extent the behavior shown is sincere. This situation also determines the reaction of the other side as well as the quality of behavior (Köse, Oral and Türesin, 2011: 170). It is different from acting superficially and deeply and feeling sincerely that a restaurant employee behaves in a friendly manner while exhibiting his work and feels sincere. In the case of passing on this feeling to the customer, the customer is satisfied with the quality of the service he receives and shapes his behavior accordingly.

Three types of emotional labor strategy are mentioned in the literature. In addition to superficial, in-depth and sincere emotional labor strategies, a superficial emotional labor display can be added, as well as emotional labor demonstrations far away from the empathy struggle and changing the emotional state without any effort behind the superficial emotional labor demonstrators spreadable. However, it is thought that midemotional labor display, which is more advanced than superficial emotional labor display, can be examined by showing it between superficial and in-depth emotional labor display.

In addition to superficial, in-depth and sincere emotional labor displays, the workers in the superficial emotional labor displays perform their tasks without any effort. Without trying to harmonize their feelings, they do not care about customer satisfaction and they serve without the harmony of the rules of conduct they are putting on.

The customer representative working at the bank's call center wants to keep the interview short while talking to the customer who has lost the credit card before flight and before the flight and the customer is warning him about this very much emotional labor demonstration-the behavior that the customer exhibited before he tried to put himself in place semi-in-depth emotional labor.

It is the emotional emotion displayed in the middle emotional labor dimension when trying to empathize without fully harmonizing certain emotional emotions between superficial emotional labor and deep emotional labor. In terms of both itself and the customer, satisfactory results at this dimension are not expected to be born at all.

\section{Consequences of Emotional Labor In Modern Organizations}

Since customer satisfaction created also reflects on the performance of the employee and when the corporations evaluate this performance, the positive attitudes enable the employee to reach career opportunities and accordingly provide the employee with the material sense of comfort. Job satisfaction is also provided if the results of emotional labor demonstrations are positive (Pugliesi, 1999: 130). Employees are mentally less worn out because of the positive behaviors they show when they act with behavioral 
codes that the institution has identified. This approach does not take into account the amount of weariness that employees will experience when exhibiting these behaviors (Güngör, 2009: 179).

Positive effects of emotional labor are observed to be less than adverse effects (Güngör Delen, 2017: 108). Research has shown that emotional labor is tiring and weary. If the emotions displayed by the employee are in conflict with the emotions they actually feel, emotional harmony is experienced. Emotional incompatibility that occurs in employees leads to stress and emotional exhaustion (Abraham, 1998: 137). Emotional incompatibility makes the employee's life difficult and reduces her success at work. If emotions are not appropriately managed, it leads to emotional feelings, lack of confidence, loss of consciousness (Gray, 2012: 4). Negative effects caused by emotional labor should be followed. Burnout is described as an occupational hazard and refers to the exhaustion of an individual's internal resources, due to failure, wear and tear, the loss of power or energy on account of overloading, or the failure to meet demands (Y1ldırım, 2013: 92).

Grandey's study found that a positive relationship between emotional labor and burnout was the cause of emotional exhaustion. In Grandey's other work, there are two reasons why an employee's emotional labor in the workplace causes exhaustion. These are the tension created by the emotional violent person. The other is the depletion of the emotional resources of the staff who are in constant need to play a role (Maslach and Jackson, 1981: 101). Deepening behavior was also found not related to emotional exhaustion (Köse, Oral and Türesin, 2011: 172). It can be said that in-depth behavior leads to more positive results than superficial emotional labor behavior.

It has been suggested that there is a relationship between superficial and negative mood in the research conducted by Judge, Woolf and Hurst, while there is no relation between job satisfaction and in-depth behavior, it is suggested that surface-based behavior causes lower job satisfaction and higher emotional exhaustion (Gülova and Palamutcuoglu, 2013: 54). Performance feedback significantly affects re-pros- pers of employees, and perhaps compensates for the harmful aspects of superficial behavior (Bakker and Demerouti, 2007: 309). Emotional labor showing decreases in performance have led to a decrease in employee satisfaction with the retreat (Goodwin et al., 2011: 538; Grandey et al., 2004: 397;

In studies investigating the effects of emotional labor behaviors on employees, it has been found that those who have high levels of superficial behaviors, emotional contradictions, stress, intention to leave work, burnout levels are higher and job satisfaction levels are lower (Kaya and Serçeoğlu, 2013: 317; Güler, 2018: 188). It is stated that the result of emotional labor behaviors for organizations is conflict and inefficiency (Bayrakç1, 2017: 583).

It is known that in the occupational groups where emotional labor is dense, it is frequently experienced to leave the work, and the absence of work is high. Employees who constantly have to be satisfied with ones, those who are in contrived behaviors are negatively affected by their emotional worlds, themselves and their relationships are disturbed and feel tired. The worker is dragged into alienation by the reason of artificial relations that he establishes in many ways. He does not feel the need to talk to people, he gets away from his family, his confidence in people decreases and he loses his respect for himself (Card, 2011: 223). 
Like other sectors in business, in banking sector, stress and burnout occur as the result of emotional labor shown in relationships with customers and friends. In addition to the bank workers policemen and teachers from the most well-known professions are exposed through the same way works. Making it feel like it does not feel and shaping its behaviors accordingly, after a while, the employees are starting to negatively affect the customers they serve.

\section{General Conclusions and Further Recommendations}

Emotions are managed and the service sector is trying to provide benefits for both employees and service areas as well as organizations. Emotional labor, also known as shadow labor, is known as the emotional effort put forth by those who work within the framework of the rules that they want to implement. The rules when emotional labor is displayed are influenced by many factors such as working environment, management style, individual characteristics of the employee. When emotional labor is exhibited, positive and negative consequences arise for employees, service providers and organizations. There is a need for an in-depth understanding of emotional labor in order to reduce or eliminate negative consequences and to provide support for emotional laborers to reach.

Emotional labor and the emotional labor shown by the employees must be understandable and emotional labor must be increased and taken out of the superficial dimension. It is necessary for organizations and individual emotional labor development to understand the necessity to make progress and to create emotional labor training, individual development activities and change and development platforms for organizations. It will increase support and supportive audits for employees expected from organizations.

Every organization is shaping its rules to achieve its own goals. It will facilitate the supervision of employees who are clearly defined and do not require initiative. The code of conduct is usually kept in organizational culture. An industry where the rules of representation are clearly evident is call centers. The rules about how to greet customers at certain time intervals during the work flow of employees are evident, for example, between 09:00 and 11:00 expecting "good days" at 11: 00-17: 00 hours, it is affected. The emotional codes of conduct can be taught and adopted for employees in three different ways.

In addition to employee and customer interaction, organizations should be assessed in relation to their relationship with the manager of the employee in emotional labor strategies, and the necessary support and guidance should be provided. From this point of view, the emotional labor to be exhibited must be able to be ruled over three hundred and sixty degrees on the basis of the organization. For the continuous development of emotional labor processes in organizations, "Emotional Labor Specialists (ELS)" requires analysis, support, training and continuous improvement activities. Thus, commitment, quality, job satisfaction, good relationships and high productivity can be achieved.

Future researchers may even say that emotional labor has become important in the service sector, and that emotional labor displays and their results continue to be closely monitored and continue to be explored in different occupational groups. In addition, studies should be continued on the variables affecting emotional labor that affect emotional labor. In order to better understand emotional labor in the work, the 
emotional labor exhibitions, the factors that are influenced when they emerged, and the results are reported. It is thought that working will benefit in the investigation and deep understanding of emotional labor.

In the service sector, it is important that the competitive conditions are sensitively changed and strengthened. In terms of organizations, employees are among the strategic success criteria in the stages of change and development. These behaviors are required to be shaped and managed correctly and effectively while waiting for the employees' behavior to be positive for their mature contributions. For this reason, in recent years, employee behaviors have gained importance in terms of organizations. Emotional labor demonstrations increase the profitability of institutions and brand value. The consequences of employee behavior affect customers and employees positively or negatively.

Emotions are often influenced by both individual and organizational factors and turn into behavior. The more effective the emotional labor demonstration, the more positive the results created for customers and organizations. Emotional labor, which is called the emotional effort exhibition by shaping the senses in the framework of the rules that they embed into the organizations, is an important success factor. There are several factors that affect emotional labor. Differences shape emotional labor displays. A deep understanding of emotional labor, together with its importance to managers, employees, customers and organizations, will facilitate the management and exhibition of its implementation, increasing its awareness of the understanding of its positive and negative consequences.

In this article, the developments in the historical process of emotional labor are addressed. This paper presents a new perspective on the application of emotional labor in the process of daily life from the past. The emotional labor process has tried to enrich by bringing a new perspective. In addition to the basic parameters of emotional labor, emotional labor orientation and resistance, they are discussed in five stages. In this way, emotional labor is drawn from a narrower perspective, drawing from a wider perspective and increasing its functionality. Thus, in addition to providing good communication and interaction in the organization, the efficiency performance and quality of the organization is also foreseen. Increasing trust and confidence at all levels of employees will contribute to a higher level of cohesion and cooperation among employees.

\section{Resources}

Abraham, R. (1998). "Emotional Dissonance In Organizations: A Conceptualization Of Consequences, Media-tors And Moderators", Lidership \& Organizational Development Journal, vol. 19, no. 3, p.137.

Altın Gülova, A. and Palamutçuoğlu, B.T. (2013). "The Role of Relative Support between Emotional Labor and Commitment to Work: A Research for the University Student Affairs Personnel", Dokuz Eylül University, İ̈BF, vol. 28, number 2.

Ashforth, B. E. and Humphrey, Ronald, H. (1993). "Emotional Labor In Service Roles: The Influence Of Identification”, Academy Of Management, vol. 18, p.89. 
Approval, M. (2011). "The Emotional Intelligence and the Emotional Strength of the Employee and Their Impact on Contextual Performance", Ege Academic View, no.4, p.589.

Bakker, A. B. and Demerouti, E. (2007). "The Job Demands-Resources Model: State Of The Art", Journal Of Managerial Psychology, vol. 22, pp. 309-328.

Bayrakçı, E. (2017). "Interaction Of Emotional Labor And Organizational Commitment: A Phenomenology Research From Bank Employees", Journal Of Current Resarches On Business And Economics, vol.7.issue.2.s.566-589.

Beğenirbaş, M. and Yalçın Can, R. (2012). "The Effects of Teacher's Personality Attributes on Emotional Labor Demonstration", Çağ University Journal of Social Sciences, No. 9, June.

Brotheridge, C.M. and Lee, R.T. (2003), "Development And Validation Of The Emotional Labor Scale”, Journal Of Occupational And Organizational Psychology, vol. 76, no. 3, pp. 365-79.

Chang, H.Y. (2011). "Restaurant Service Providers Emotional Labor: The Antecedents And Effects On Emplo-yees Intention To Leave", Purdue University, West Lafayette, Indiana.

Cheng, C. Bartram, T. Karimi, L. and Leggat, S.G. (2013). "The Role Of Team Climate In The Management Of Emotional Labor: Implications For Nurse Retention", Journal of Advanced Nursing, vol. 69 (12), pp. 2812-2825.

Diefendorff, J.M.ve Gosserand, R.H. (2003). "Understanding The Emotional Labor Process: A Control Theory Perspective", Journal Of Organizational Behaviour, vol.11.

Duran E. ve Gümüş, M. (2013). "Turizm Lisans Öğrencilerinin Duygusal Emek Deneyimlerinin Kariyer Tercihlerine Etkileri”, Dokuz Eylül Üniversitesi Sosyal Bilimler Dergisi, cilt.15, s.237.

Grandey, A.A. (2000). "Emotion Regulation In Workplace: A New Way To Conceptualize Emotional Labor", Journal of Occupational Health Psychology, vol. 5, no. 1, p.5.

Grandey, A. A. (2003). "When the Show Must Go On: Surface Acting And Deep Acting As Determinants Of Emotional Exhaustion And Peer-Rated Service Delivery" Academy Of Management Journal, vol. 46 (1), pp. 86-96.

Grandey, A. A., Dickter, D. N., \& Sin, H. P. (2004). "The Customer Is Not Always Right: Customer Aggression And Emotion Regulation Of Service Employees", Journal of Organizational Behavior, vol. 25 (3), pp. 397-418.

Grandey, A. A., Diefendorff, J. M. and Rupp, D.E. (2013). "Bringing Emotional Labor Into Focus: A Review And Integration Of Three Research Lenses, Emotional Labor In The 21st Century" by Taylor And Francis, New York.

Gray, B. (2012). Face To Face With Emotions In Health And Social Care, Springer, London.

Güler, H.N. (2018). "Kişilik, Örgütsel Güven Ve Bağlılığın Duygusal Emeğe Etkileri İle İşten Ayrılma Niyeti Arasındaki İlişkinin Belirlenmesine Yönelik Bir Araştırma", İstanbul Aydın Üniversitesi Sosyal Bilimler Enstitüsü, Doktora Tezi, s.188. 
Güngör, M. (2009). "Emotional Labor Concept: Process and Results", Public Works, issue 1, pp. 172-173.

Güngör Delen M. (2017). Emotional Labor \& Tinsel Emek, Türkmen Bookstore, Istanbul.

Hall, T.H. (2015). Emotional Diplomacy: Official Emotion On The International Stage, Cornell University Press, London, p.22.

Hennig-Thurau, T., Groth, M., Paul, M., and Gremler, D. D. (2006). "Are All Smiles Created Equal? How Emotional Contagion and Emotional Labor Affect Service Relationships, "Journal of Marketing, vol. 70, pp. 58-73.

Hochschild, A. (1979). "Emotion Work, Feeling Rules and Social Structure”, American Journal of Sociology, vol. 85, pp. 515-575.

Hochschild, A. (2003). The Managed Hearth of Commercialization of Human Feeling, University of California Press, London.

Hsieh, C.W. (2009). Emotional Labor in Public Service Roles: A Model of Dramaturgical And Dispositional Approaches, (Unpublished PhD Thesis), Florida State University.

James, N. (1993). "Divisions Of Emotional Labor: Disclosure And Cancer, In S. Fineman (Ed.), Emotion In Organizations”, pp. 94-117. London, Sage.

Kaya, U. and Serçeoglu, N. (2013). "Alienation to Work in Emotion Workers: A Research in the Service Sector", Labor and Society, issue 1, p.317.

Koys, D. J. (2001). "The Effects of Employee Satisfaction, Organizational Citizenship Behavior And Turnover On Organizational Effectiveness: A Unit-Level, Longitudinal Study", Personnel Psychology, vol. 54 (1), pp. 101-114.

Köse, S. Oral, L. and Türesin, H. (2011). "A Research in the Health Sector on the Relation of Emotional Labor Behaviors to Burnout Levels of Occupants", Journal of Business Administration, p.170.

Mark, A. (2005). "Emotion In Healthcare Organization", Journal Of Health Organization And Management, Emerald Group Publishing Limited.

Maslach, C. and Jackson, S.E. (1981). The Measurement Of Experimental Burnout, Journal Of Occupational Behavior, vol. 2, pp.99-113.

Mastracci, S.H. Guy, M.E. and Newman, M.A. (2014). "Emotional Labor And Crisis Response: Working On The Razor's Edge", Taylor And Francis, London And New York.

Morris, J.A. Feldman, D.C. (1996). "The Dimension, Antecedents And Consequences Of Emotional Labor”, Academy Of Management Journal, p.17.

Özgen, I. (2010). Emotional Labor in Tourism Enterprises, Detay Publishing.

Pala, T. and Surgevil, O. (2016). "Emotional Labor Scale: Scale Development, Reliability and Validity Study", Aegean Academic View, vol.16, no.4, pp.773-787.

Pugliesi, K. (1999). "The Consequences of Emotional Labor: Effects on Work Stress, Job Satisfaction And Well-Being", Motivation And Emotion, vol. 23 (2), p.130. 
Saks, K. (1990). "Does It Pay To Care? Circles Of Care: Work And Identity In Women's Lives", Suny Press, New York, pp. 111-136.

Smith, P. (1992). The Emotional Labor Of Nursing. London: Macmillan.

Tasi, W. and Huang, Y. (2002). "Mechanisms Linking Employee Affective Delivery And Customer Behavioral Intentions"; Journal Of Applied Psychology, pp. 160-169.

Theodosius, C. (2008). Emotional Labor In Healthcare: The Unmanaged Hearth Of Nursing, Routledge, New York.

Totterdell, P., and Holman, D. (2003). "Emotion Regulation In Customer Service Roles: Testing A Model Of Emotional Labor", Journal Of Occupational Health Psychology, vol.8 (1), pp.55-73.

Xiao-Yu, L. Ho, K. K., Long, Z.W. and Xiao, M.Z. (2016). "Emotional Labor and Family Quality: The Role of Work-Family Positive Spillover", The International Journal of Human Resource Management, pp.1-26.

War, A.C. (2012). "The Impact of School Managers 'Emotional Intelligence and Emotional Labor Qualifications on the Level of Teachers' Job Satisfaction", Dumlupınar University Journal of Social Sciences, p.57.

Y1ldırım, M. H. and Erul, E.E. (2013). "The Impact of Emotional Labor Behavior on the Level of Burnout of Occupants", Journal of Organization and Management Sciences, vol.5, no.1, p.92.

Yin, H. and Lee, J.C.K. (2012). "Be Passionate, But Be Rational As Well: Emotional Rules For Chinese Teachers Education, vol.28, s.56-65. 